\title{
DESPERATE SOFTWOOD LUMBER COMPANIES?: THE CANADA-U.S. SOFTWOOD LUMBER DISPUTE AND NAFTA CHAPTER 11
}

\author{
LINDA C. REIF*
}

The international trade law area is an arena where international tribunals are increasingly being used for the settlement of disputes. The Canada-U.S. softwood lumber dispute is a key example of how trade disputes have been made even more convoluted and intractable by the availability of multiple international and domestic fora for dispute settlement.

The author of this article explores the use of NAFTA c. 11 in the softwood lumber disputes and argues that it will be of limited use for both Canadian and U.S. softwood lumber companies in future disputes. The author posits that c. 11 will remain available solely to contest U.S. measures affecting Canadian softwood lumber to the extent they do not fall within U.S. antidumping and countervailing duty law (as defined under NAFTA c. 19).

\begin{abstract}
Le secteur du droit commercial international est un domaine où l'on a de plus en plus recours aux tribunaux internationaux pour régler les différends. Le différend sur le bois d'œuvre qui existe entre le Canada et les États-Unis illustre parfaitement comment les conflits commerciaux sont devenus encore plus alambiqués et récalcitrants par l'existence de tribunes de règlement internationales et nationales. L'auteur de l'article explore le recours à l'article 11 de l'ALÉNA dans les conflits sur le bois d'œuvre et fait valoir que cet article n'aidera pas vraiment les sociétés de bois d'œuvre canadiennes ou américaines dans le cas de conflits futurs. L'auteur précise que l'article 11 sert uniquement pour contester les mesures américaines ayant une incidence sur le bois d'œuvre canadien dans la mesure où elles ne tombent pas sous la loi antidumping et la loi sur les droits compensateurs des États-Unis (tel que défini en vertu de l'article 19 de l'ALÉNA).
\end{abstract}

\section{TABLE OF ConTENTS}

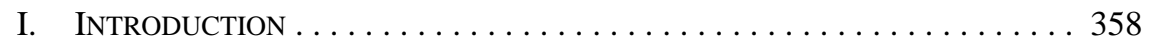

II. Multiple Fora For CANADA-U.S. TRAde DisPute RESOlUtion . . . . 359

III. THE WTO/NAFTA ERA: MULTIPLE FORA FOR THE

SOFTWOOD LUMBER DISPUTE $\ldots \ldots \ldots \ldots \ldots \ldots \ldots \ldots \ldots \ldots \ldots \ldots$

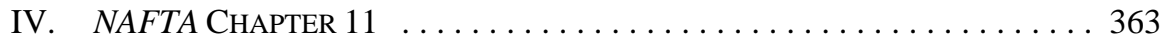

V. NAFTA CHAPTER 11, POPE \& TALBOT INC. V. CANADA, AND THE 1996-2001 CANAdA-U.S. SOFTWOOd LuMBer AgREEMENT . . . . . 365

VI. NAFTA CHAPTER 11, CANFOR CORPORATION AND TERMINAL FOREST PRODUCTS LTD. V. U.S.A.: THE REVIEWABILITY OF NAFTA AD/CVD ACTIONS AND THE BYRD AMENDMENT $\ldots \ldots \ldots \ldots \ldots \ldots \ldots \ldots$

VII. THE 2006 CANADA-U.S. SOFTWOOd LuMBER AGREEMENT $\ldots \ldots \ldots . . . .374$

VIII. NAFTA CHAPTER 11, SOFTWOOD LUMBER, AND IMPLICATIONS FOR THE FUTURE $\ldots \ldots \ldots \ldots \ldots \ldots \ldots \ldots \ldots \ldots \ldots$

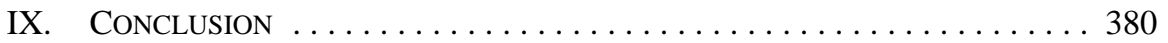

* $\quad$ CN Professor of International Trade, Faculty of Law, University of Alberta. I am very grateful to Lindy Shearer, LL.B. 2007, for her valuable research assistance. I also thank Donald McRae, Greg Anderson, and J. Cameron Mowatt for their helpful comments on an earlier draft of this article. 


\section{INTRODUCTION}

In recent years, international law scholars have turned their attention to the proliferation of international tribunals for the settlement of disputes. The international trade law area is one such arena where international tribunals are multiplying. In addition to the World Trade Organization (WTO) dispute settlement mechanism, ${ }^{1}$ various regional economic integration agreements such as the North American Free Trade Agreement ${ }^{2}$ also have dispute settlement mechanisms. These multiple venues may offer a choice of the most advantageous fora or, in some cases, concurrent fora may be available with the possibility of conflicting decisions being rendered. ${ }^{3}$

The four bouts of the Canada-U.S. softwood lumber dispute have been interspersed by managed trade agreements that have proved to be only temporary panaceas. The Canada-U.S. softwood lumber drama is a prime example of how the availability of multiple international and domestic fora for dispute settlement have made a complex bilateral trade dispute even more convoluted and intractable. The softwood lumber dispute in its most recent iteration has involved complaints lodged with the WTO, NAFTA c. 19, NAFTA c. 11, and the U.S. courts. While most of the complaints have revolved around subsidies and dumping issues, softwood lumber companies have also tried to use NAFTA c. 11 which contains host state investment obligations and a host state-investor arbitration dispute settlement mechanism.

This article explores the use of NAFTA c. 11 in the softwood lumber saga. Has the use of c. 11 been a desperate ploy on the part of these companies or a viable strategy to obtain redress for Canadian and U.S. government intervention of one type or another in the North American softwood lumber market? Given the history of the softwood lumber dispute, it is likely that there will be more episodes in this saga. In this article I argue that, based on NAFTA government action and c. 11 arbitral jurisprudence, NAFTA c. 11 will be of limited utility for Canadian softwood lumber companies in future disputes involving U.S. countervailing/anti-dumping actions against Canadian softwood lumber imports. Further, the use of c. 11 by U.S. softwood lumber companies with Canadian investments to contest export controls in periodic managed trade agreements will be excluded by those treaties unless it can be argued successfully that the treaty exclusion is contrary to international law. Chapter 11 remains open to contest U.S. measures affecting Canadian softwood lumber only to the extent that they can be classified as not falling within U.S. anti-dumping and countervailing

$1 \quad$ Agreement Establishing the World Trade Organization, 15 April 1994, 1867 U.N.T.S. 154, 33 I.L.M. 1144 (entered into force 1 January 1995) [WTO Agreement].

2 North American Free Trade Agreement Between the Government of Canada, the Government of Mexico and the Government of the United States, 17 December 1992, Can. T.S. 1994 No. 2, 32 I.L.M. 289 (entered into force 1 January 1994) [NAFTA].

See e.g. David A. Gantz, "Dispute Settlement Under the NAFTA and the WTO: Choice of Forum Opportunities and Risks for the NAFTA Parties” (1999) 14 Am. U. Int'l L. Rev. 1025; Eric J. Pan, "Assessing the NAFTA Chapter 19 Binational Panel System: An Experiment in International Adjudication” (1999) 40 Harv. Int'l L.J. 379 at 392; Linda C. Reif, “NAFTA, WTO and FTAA: Choice of Forum in Dispute Resolution” in Edward J. Chambers \& Peter H. Smith, eds., NAFTA in the New Millennium (La Jolla, Cal.: Centre for U.S.-Mexican Studies; Edmonton: University of Alberta Press, 2002) 447; Kyung Kwak \& Gabrielle Marceau, “Overlaps and Conflicts of Jurisdiction Between the World Trade Organization and Regional Trade Agreements” (2003) 41 Can. Y.B. Int'l Law 83; Joost Pauwelyn, "Adding to Sweeteners to Softwood Lumber: The WTO-NAFTA 'Spaghetti Bowl' is Cooking,” Editorial Comment, (2006) 9 J. Int'l Econ. L. 197. 
duty law as defined under NAFTA c. 19. The c. 11 softwood lumber cases also underline the generally careful interpretation of c. 11 substantive provisions by the arbitral tribunals and the inclination of NAFTA governments to try to narrow the application of NAFTA c. 11 by agreement.

\section{Multiple Fora for Canada-U.S. Trade Dispute Resolution}

Canada and the U.S. are both parties to the WTO Agreement (including the General Agreement on Tariffs and Trade ${ }^{4}$ ) and the NAFTA, with the result that the two nations are bound by the substantive rights and obligations in each treaty and the dispute settlement mechanisms of one or both treaties may be available in Canada-U.S. trade and investment disputes.

There are numerous trade and trade-related obligations that are found in both the WTO Agreement and the NAFTA, a full survey of which is beyond the scope of this article. The rules governing subsidization and dumping of goods and permissible importing government reaction to these unfair trade practices in the form of countervailing duties (CVDs) and antidumping duties (ADDs) are relevant to the softwood lumber dispute. ${ }^{5}$ Substantive legal obligations in these areas are found in the WTO Agreement, ${ }^{6}$ notably in the GATT $1994,{ }^{7}$ the Anti-Dumping Agreement, ${ }^{8}$ and the Agreement on Subsidies and Countervailing Measures. ${ }^{9}$ The WTO, however, has few rules covering investment relations, primarily covering traderelated investment measures (TRIMs). ${ }^{10}$ The WTO has only one dispute settlement mechanism, available for inter-state disputes, governed by the Understanding on Rules and Procedures Governing the Settlement of Disputes. ${ }^{11}$ The WTO DSU is more legalistic in nature compared to the former GATT procedures, with the result that it has become more attractive as a venue for trade dispute resolution. ${ }^{12}$

WTO Agreement, supra note 1, including General Agreement on Tariffs and Trade 1994, Annex 1A [GATT 1994].

5 A subsidy is a financial contribution or income/price support given by a government to the benefit of producers whose goods enter the export market. Dumping is exporting company conduct where its goods are sold in the export market at a price that is lower than the price charged in the domestic market (normal value). A process takes place in the importing state to determine the amount of the subsidy/dumping and whether there has been material injury or threat thereof to the domestic industry in the importing state caused by the imports. A CVD/ADD is calculated in an amount to neutralize the amount of the subsidy/dumping margin in order to restore fair trading conditions. See e.g. Gary Horlick, WTO and NAFTA Rules and Dispute Resolution: Selected Essays on Antidumping, Subsidies and other Measures (London: Cameron May, 2003); Mitsuo Matsushita, Thomas J. Schoenbaum \& Petros C. Mavroidis, The World Trade Organization: Law, Practice, and Policy, 2d ed. (Oxford: Oxford University Press, 2006) at 331-436. Supra note 4.

8 Agreement on Implementation of Article VI of the General Agreement on Tariffs and Trade 1994, Annex 1A, WTO Agreement, supra note 1 [AD Agreement]. Annex 1A, WTO Agreement, supra note 1 [SCM Agreement]. [TRIMs Agreement]. The TRIMs Agreement requires that trade-related investment measures must be consistent with the national treatment principle in art. III and the prohibition on quantitative restrictions in art. XI:1 of GATT 1994, covering, for example, domestic content requirements and export restrictions. Annex 2, WTO Agreement, supra note 1 [DSU].

Matsushita, Schoenbaum \& Mavroidis, supra note 6 at 103-39. 
While the NAFTA includes extensive obligations governing trade and investment, it does not contain substantive principles on subsidies, dumping, and anti-dumping and countervailing duty (AD/CVD) actions. The negotiators of the earlier Free Trade Agreement between the Government of Canada and the Government of the United States of America ${ }^{13}$ had been unable to agree on inclusion of such rules, CUSFTA provisions for negotiation of common principles came to naught, and this state of affairs was crystallized in the NAFTA. ${ }^{14}$ As discussed further below, NAFTA c. 11 contains extensive legal obligations for a NAFTA host state with respect to foreign investment and investors from another NAFTA state.

In contrast to the WTO, the NAFTA has a number of dispute settlement mechanisms open to state and/or non-state actors. NAFTA c. 20 is the inter-state dispute settlement mechanism and it contains provisions on choice of forum between it and the WTO DSU, thereby avoiding parallel fora when a purely inter-state dispute arises between Canada and the U.S. ${ }^{15}$ As discussed in more detail below, NAFTA c. 11 provides for international arbitration of NAFTA host state-foreign investor disputes.

NAFTA c. 19 provides for binational panel review of final domestic subsidy and dumping determinations made by the importing state as an optional replacement for domestic judicial review. ${ }^{16}$ Where the U.S. is the importing state, the panel review replaces review by the U.S. Court of International Trade (CIT) of determinations made by the Department of Commerce (DOC, subsidy/dumping findings) and the International Trade Commission (ITC, material injury determinations). ${ }^{17} \mathrm{~A}$ panel applies the domestic law of the importing state on review of administrative action that would have been applied by the reviewing court. ${ }^{18}$ A panel can only uphold a final agency determination or remand it for action not inconsistent with the panel's determination. ${ }^{19}$ Only the relevant NAFTA states are empowered to initiate c. 19 cases but the companies that would have had the right to appear in the domestic review process have the right to appear before the panel. ${ }^{20}$ Chapter 19 also provides for an Extraordinary Challenge Committee (ECC) to review panel determinations in limited situations. ${ }^{21}$ The NAFTA and its predecessor CUSFTA c. 19 binational panel review processes have been used extensively, and commentators feel that, with a few exceptions (notably the softwood lumber dispute), the c. 19 process has worked well. ${ }^{22}$

2 January 1988, Can. T.S. 1989 No. 3, 27 I.L.M. 293 (entered into force 1 January 1989) [CUSFTA]. Allan Gotlieb, the Washington diaries: 1981-1989 (Toronto: McClelland \& Stewart, 2006) at 484-93; Michael Hart, Decision at Midnight: Inside the Canada-US Free-Trade Negotiations (Vancouver: University of British Columbia Press, 1994) at 333-35.

DSU, supra note 11, art. 23(1) requires that allegations of breach of or nullification and impairment of benefits under WTO covered agreements be decided under the DSU. NAFTA, supra note 2, art. 2005 allows the complaining state to decide on use of the WTO DSU or NAFTA c. 20 in most cases, although some disputes must be settled under c. 20, resulting in a choice of forum between the DSU and NAFTA c. 20 in some cases: Gantz, supra note 3 at 1091, 1096-106.

NAFTA, ibid., art. 1904.

Ibid., art. 1904(3), annex 1911.

Ibid.

Ibid., art. 1908(4).

Ibid., arts. 1904(2), (7), 1911.

Ibid., art. 1904(13), annex 1904.13.

Pan, supra note 3; Patrick Macrory, Dispute Settlement in the NAFTA: A Surprising Record of Success, C.D. Howe Institute Commentary, The Border Papers, No. 168 (Toronto: C.D. Howe Institute, 2002). But see Robert Howse, Settling Trade Remedy Disputes: When the WTO Forum is Better Than the NAFTA, C.D. Howe Institute Commentary, Trade Policy, No. 111 (Toronto: C.D. Howe Institute, 1998). 


\section{THE WTO/NAFTA ERA: MULTIPLE FORA FOR THE SOFTWOOD LUMBER DISPUTE}

The first episodes of the softwood lumber saga — Lumber I (1982-1983) and Lumber II (1986) — were relatively simple affairs. ${ }^{23}$ By the time Lumber III (1991-1994) commenced, the CUSFTA binational panel process was in force and was used by Canada to contest the U.S. CVD determinations levied on Canadian softwood lumber in several c. 19 panel review actions, followed by unsuccessful resort to an ECC by the U.S., the refund of duties by the U.S. government in 1994, and the subsequent negotiation of the 1996-2001 Softwood Lumber Agreement between the Government of Canada and the Government of the United States of America. $^{24}$

Lumber IV (2001-2006) illustrated that in the WTO/NAFTA era with a Canada-U.S. subsidies and/or dumping dispute it is possible for concurrent fora to be used by affected state and non-state parties. ${ }^{25}$ On the expiration of the 1996 SLA in 2001, petitions alleging both Canadian government subsidization of softwood lumber and dumping by Canadian businesses were filed by U.S. producers. The final determinations of the DOC found that the lumber was being subsidized and dumped, and the ITC found there was threat of material

23 In Lumber I, the U.S. Coalition for Fair Lumber Imports (CFLI) petitioned the U.S. DOC in 1982 for CVDs to be levied against Canadian softwood lumber imports, arguing that stumpage fees charged by the Canadian governments for the sale of timber on Crown lands constituted a subsidy. The DOC issued a final negative CVD determination and dismissed the petition. In Lumber II, another CVD action was brought against the Canadian stumpage regime. The DOC made a preliminary determination that there was a subsidy of 15 percent and the ITC found material injury, resulting in the imposition of CVD duties. In December 1986, the two governments adopted a Memorandum of Understanding (MOU) in which Canada agreed to impose a 15 percent export tax on softwood lumber exported to the U.S. in return for U.S. termination of the CVD investigation and return of monies collected. Canada also made a complaint under the GATT, arguing the U.S. had breached the Tokyo Round subsidies code in initiating the CVD action: United States: Initiation of a Countervailing Duty Investigation into Softwood Lumber Products From Canada (1987), GATT Doc. SCM/83, 34th Supp. B.I.S.D. (1987) 194 (parties indicated MOU was a mutually satisfactory resolution of dispute). On 4 October 1991, the Canadian government withdrew from the MOU on the basis that it had raised stumpage fees high enough to eliminate any subsidization: see Iain Sandford, "Determining the Existence of Countervailable Subsidies in the Context of the Canada-United States Softwood Lumber Dispute: 1982-2005” (2005) 43 Can. Y.B. Int'l Law 297 at 299-304.

2429 May 1996, Can. T.S. 1996 No. 16, 35 I.L.M. 1197 (entered into force 1 April 1996 to 31 March 2001) [1996 SLA]. On the termination of the MOU, the U.S. DOC self-initiated another CVD investigation. A positive final DOC determination and an ITC finding of material injury resulted in the imposition of a 6.51 percent CVD. See CUSFTA binational panel reviews launched by Canada: $R e$ Certain Softwood Lumber Products from Canada, USA-92-1904-01 (DOC), Decision of the Panel (6 May 1993), Decision of the Panel on Remand (17 December 1993) (Ch. 19 Panel); Re Certain Softwood Lumber Products from Canada, USA-92-1904-02 (ITC), Decision of the Panel (26 July 1993), Decision of the Panel on Remand (28 January 1994), Decision of the Panel on Second Remand (6 July 1994) (Ch. 19 Panel), decisions available online: NAFTA Secretariat <http://nafta-sec-alena.org>. See also $R e$ Certain Softwood Lumber Products from Canada, ECC-94-1904-01USA, Memorandum Opinions and Order (3 August 1994) (ECC), online: NAFTA Secretariat <http://www.nafta-sec-alena.org>. For a discussion of the 1996 SLA see infra notes 126-36 and accompanying text.

25 Greg Anderson, "Can Someone Please Settle This Dispute? Canadian Softwood Lumber and the Dispute Settlement Mechanisms of the NAFTA and the WTO” (2006) 29 World Economy 585; Chi Carmody, “International Decisions — Softwood Lumber Dispute (2001-2006)” (2006) 100 Am. J. Int’l L. 664; Sandford, supra note 23. 
injury to the U.S. industry, resulting in the imposition of substantial CVDs and ADDs. ${ }^{26}$ Requests for NAFTA c. 19 binational panel reviews of the final DOC and ITC determinations were initiated by Canada, resulting in multiple panel determinations in favour of Canada and another unsuccessful ECC bid by the U.S. ${ }^{27}$ The Canadian government also launched complaints against the U.S. under the WTO concerning U.S. measures in the softwood lumber dispute, with mixed success. ${ }^{28}$ The Canadian government and producers, frustrated by U.S. DOC and ITC intransigence ultimately turned to the U.S. CIT which in turn handed down a series of judgments upholding Canadian arguments. ${ }^{29}$ Further, NAFTA c. 11 was also used by Canadian softwood lumber companies as another venue to attack the U.S. AD/CVD determinations in Lumber IV.

Slaughter and Burke-White have characterized NAFTA c. 19 as an international law mechanism to "backstop" its counterpart national institutions when they fail to act correctly under domestic law. ${ }^{30}$ However, Lumber IV has illustrated that the c. 19 backstop is not fail-

26

Sandford, ibid. at 310-312. The initial combined rate was 27.22 percent which, influenced by Canadian complaints, was reduced several times before the 2006 settlement.

Re Certain Softwood Lumber Products from Canada: Final Affirmative Antidumping Determination, USA-CDA-2002-1904-02 (DOC), Decision of the Panel (17 July 2003), Decision of the Panel Respecting Remand Redetermination (5 March 2004), Decision of the Panel Following Remand (9 June 2005), Decision of the Panel Respecting Motions to Dismiss (5 January 2007) (Ch. 19 Panel); Re Certain Softwood Lumber Products from Canada: Final Affirmative Countervailing Duty Determination, USA-CDA-2002-1904-03 (DOC), Decision of the Panel (13 August 2003), Decision of the Panel on Remand (7 June 2004), Decision of the Panel on Second Remand (1 December 2004), Decision of the Panel on Third Remand (23 May 2005), Decision of the Panel on the Fourth Remand Determination (5 October 2005), Decision of the Panel on the Fifth Remand Determination (17 March 2006) (Ch. 19 Panel); Re Certain Softwood Lumber Products from Canada: Final Affirmative Threat of Injury Determination, USA-CDA-2002-1904-07 (ITC), Decision of Panel (5 September 2003), Remand Decision of the Panel (19 April 2004), Second Remand Decision of the Panel (31 August 2004) (Ch. 19 Panel); Re Certain Softwood Lumber Products from Canada, ECC-2004-1904-01USA, Opinion and Order of the Extraordinary Challenge Committee (10 August 2005) (ECC), all decisions available online: NAFTA Secretariat <http://nafta-sec-alena.org>; and six other c. 19 panel reviews still active at time of 2006 settlement.

United States — Continued Dumping and Subsidy Offset Act of 2000 (2003), WTO Doc. WT/DS217, 234/AB/R (Appellate Body Report); United States - Section 129(c)(1) of the Uruguay Round Agreements Act (2002), WTO Doc. WT/DS221/R (Panel Report); United States - Preliminary Determinations With Respect to Softwood Lumber from Canada (2002), WTO Doc. WT/DS236/R(Panel Report); United States - Final Countervailing Duty Determination With Respect to Certain Softwood Lumber from Canada (2004), WTO Doc. WT/DS257/AB/R (Appellate Body Report); United States Final Countervailing Duty Determination With Respect to Softwood Lumber From Canada - Recourse by Canada to Article 21.5 of the DSU (2005), WTO Doc. WT/DS257/AB/RW (Appellate Body Report); United States - Investigation of the International Trade Commission in Softwood Lumber From Canada - Recourse to Article 21.5 of the DSU by Canada (2005), WTO Doc. WT/DS277/RW (Panel Report); United States — Final Dumping Determination on Softwood Lumber From Canada (2004), WTO Doc. WT/DS264/AB/RW (Appellate Body Report); United States - Final Dumping Determination on Softwood Lumber From Canada-Recourse to Article 21.5 of the DSU by Canada (2006), WTO Doc. WT/DS264/AB/RW (Appellate Body Report), all decisions available online: WTO $<$ http://docsonline.wto.org/gen_search. asp>.

See Canadian Lumber Trade Alliance v. United States, 425 F.Supp. 2d 1321 (Ct. Int'l Trade 2006) [Canadian Lumber]; Tembec, Inc. v. United States, 441 F.Supp. 2d 1302 (Ct. Int'l. Trade 2006); Tembec, Inc. v. United States, 461 F.Supp. 2d 1355 (Ct. Int'l Trade 2006); Tembec, Inc. v. United States, 475 F.Supp. 2d 1393 (Ct. Int'l Trade 2007). But for the 2006 settlement, these decisions likely would have been appealed to the U.S. Court of Appeals (Fed. Cir.).

Anne-Marie Slaughter \& William Burke-White, "The Future of International Law is Domestic (or, The European Way of Law)” (2006) 47 Harvard Int’l L.J. 327 at 339-41. 
safe, with a ping-pong relationship developing between the panels and the U.S. domestic agencies, parties moving around the backstop to access other available venues and the dispute being settled temporarily by yet another managed trade agreement. The multiple fora used in Lumber IV illustrated the use of: concurrent fora where more than one trade regime is applicable (WTO DSU and NAFTA c. 19), concurrent fora within one trade regime (NAFTA cc. 19 and 11), and the addition of U.S. domestic courts. The potential for conflicting results emanating from the different decision makers given the different legal frameworks within which they operate and the broadening of the dispute to include traderelated investment matters are ensuing issues.

Much of the commentary on the long-running Canada-U.S. softwood lumber dispute has focused on the WTO and NAFTA c. 19 cases. ${ }^{31}$ However, the attempts by softwood lumber industry players to use NAFTA c. 11 to obtain relief from government action negatively affecting their trans-border business interests should also be explored. Trade-related measures (including those affecting softwood lumber) can have an impact on NAFTA state investment obligations in c. $11 .^{32}$

\section{NAFTA CHAPTER 11}

The CUSFTA c. 16 was a start in the direction of investment liberalization. ${ }^{33}$ It imposed only prospective and limited substantive obligations on CUSFTA host states with respect to investors and investment from the other party and it did not create a host state-investor dispute settlement mechanism. ${ }^{34}$

NAFTA c. 11 went much further, in essence importing the bilateral investment treaty (BIT) model into the trilateral NAFTA. ${ }^{35}$ While many of the several thousand BITs in existence are between developed and developed states, NAFTA c. 11 is one of the few instances where a $B I T$ equivalent is in place for two industrialized states where there are substantial two-way investment flows. ${ }^{36}$ NAFTA c. 11 , s. A contains an extensive array of NAFTA host state obligations covering "measures ... relating to" investors and investments from the other

$31 \quad$ See e.g. Anderson, supra note 25; Carmody, supra note 25; Pauwelyn, supra note 3.

32 Indeed, NAFTA, supra note 2, art. 1106 expressly addresses trade-related investment measures.

33 Supra note 13.

34 CUSFTA, ibid., ch. 16. art. 1608(4) only required the two state parties to give their "fullest consideration" to settling disputes under the c. 18 inter-state procedures.

35 See J.C. Thomas, “Investor-State Arbitration Under NAFTA Chapter 11” (1999) 37 Can. Y.B. Int’l Law 99; Laura Ritchie Dawson, ed., Whose Rights? The NAFTA Chapter 11 Debate (Ottawa: Centre for Trade Policy and Law, 2002); Meg Kinnear \& Robin Hansen, “The Influence of NAFTA Chapter 11 in the BIT Landscape” (2005) 12 U.C. Davis J. Int'l L. \& Pol’y 101; Alan S. Alexandroff, ed., Investor Protection in the NAFTA and Beyond: Private Interest and Public Purpose, Policy Study 44, The Border Papers (Toronto: C.D. Howe Institute, 2006).

36 But see the Free Trade Agreement between Australia and the United States of America, 18 May 2004, [2005] ATS 1 (entered into force 1 January 2005), art. 11.16 (no host state-investor arbitral mechanism in AUSFTA, consultations on investor-state dispute settlement), online: Office of the United States Trade Representative <http://www.ustr.gov/Trade_Agreements/Bilateral/Australia_FTA/Final_Text/ Section_Index.html $>$ [AUSFTA]. By the end of 2005 there were approximately 2,495 BITs in existence: United Nations Conference on Trade and Development (UNCTAD), World Investment Report 2006. FDI From Developing and Transition Economies: Implications for Development (Switzerland: United Nations, 2006), online: UNCTAD <http://unctad.org/en/docs/wir2006_en.pdf> at xix. 
NAFTA states. ${ }^{37}$ These include national treatment in art. 1102, most-favored nation treatment in art. 1103, minimum standard of treatment in art. 1105, prohibition of performance requirements in arts. 1106 and 1107, prohibitions of restrictions on transfers of profits, capital, etc. in art. 1109, and a provision that provides for compensation in the event of expropriation of foreign investment in art. 1110. Pursuant to art. 1108 and annexes to the NAFTA, there are various reservations and exceptions to arts. 1102, 1103, 1106, and 1107. Covered investments are defined very broadly, and an investor includes one that "seeks to make, is making or has made an investment." 38

Section B of c. 11 contains dispute settlement provisions that permit an investor of one NAFTA state who has covered investments in another NAFTA state to launch international arbitration proceedings against the host state, alleging that the NAFTA host government has violated one or more of its obligations in s. A causing the investor losses or damages. ${ }^{39}$ Investors of one NAFTA state which own or control enterprises directly or indirectly in another NAFTA host state can also bring claims. ${ }^{40}$ There are some conditions precedent and time limitations to an investor claim. ${ }^{41}$ In particular, claimants must waive their right to initiate or continue an action concerning the government measure in question in any NAFTA state court/tribunal or other dispute settlement procedure, except for proceedings for injunctive, declaratory, or other extraordinary relief not involving the payment of damages. ${ }^{42}$

The host state-foreign investor arbitrations are to be held pursuant to ICSID Convention rules, the ICSID Additional Facility Rules, or the UNCITRAL Arbitration Rules. ${ }^{43}$ In most cases three arbitrators are appointed to determine the dispute and arbitrators do not have to be citizens of the NAFTA states. ${ }^{44}$ The arbitral tribunal applies relevant NAFTA provisions and applicable rules of international law to decide the issues in dispute. ${ }^{45}$ The latter enables c. 11 arbitral tribunals to apply relevant customary international law norms governing the treatment of foreign investment. However, art. 1131(2) empowers the NAFTA Free Trade Commission (the three trade ministers) to issue interpretations of NAFTA provisions which are binding on c. 11 arbitral tribunals. Tribunals are empowered to award monetary

NAFTA supra note 2, art. 1101(1). In NAFTA, art. 201 outlines that "measure includes any law, regulation, procedure, requirement or practice.”

Ibid., arts. 1139 and 201.

Ibid., arts. 1116, 1122.

Ibid., art. 1117.

Ibid., arts. 1116(2), 1117(2), 1121.

Ibid., arts. 1121(1)(b), 1121(2)(b).

Ibid., art. 1120. See Convention on the Settlement of Investment Disputes between States and Nationals of Other States [ICSID Convention], Rules Governing the Additional Facility for the Administration of Proceedings by the Secretariat of the International Centre for Settlement of Investment Disputes [ICSID Additional Facility Rules], online: ICSID <http://www.worldbank.org/icsid/about/about.htm>; Arbitration Rules of the United Nations Commission on International Trade, GA Res. 31/98, UN GAOR, 31st Sess., Supp. No. 17, UN Doc. A/31/17 (1976) [UNCITRAL Arbitration Rules]. Currently, only the U.S. is an ICSID Convention contracting party, Canada signed the ICSID Convention in December 2006 but has not ratified it by mid-2007, and Mexico is not a signatory. The ICSID Convention rules will not be an option until Canada ratifies the Convention, and then it can be used only for Canadian investor-U.S. and U.S. investor-Canada disputes. The UNCITRAL Arbitration Rules can be used for all c. 11 arbitrations and the ICSID Additional Facility Rules can be used where one of the relevant states is an ICSID Convention contracting party. NAFTA, ibid., arts. 1123-26.

Ibid., art. 1131(1). 
damages/interest and restitution of property to successful claimants in a final award. ${ }^{46}$ However, tribunals cannot order the termination of an offending government measure.

Arbitral awards rendered under NAFTA c. 11 are legally binding on the parties in respect of that case only and the award can be enforced in the domestic sphere. ${ }^{47}$ The principle of stare decisis is not applicable to awards, although tribunals may be influenced by the reasoning in earlier awards in reaching their decisions.

The c. 11 dispute settlement mechanism can be directly accessed by non-state actors, specifically corporate and individual investors, who have taken advantage of this transnational aspect of the NAFTA. There have been numerous c. 11 claims launched by investors against NAFTA states since 1997 — and all three states have been targeted. ${ }^{48}$ The c. 11 arbitral award jurisprudence and the procedural innovations developed by both the tribunals and the NAFTA governments have in turn influenced the evolution of international investment law. ${ }^{49}$ It has also been observed that investors, in contrast to the NAFTA governments:

do not have the same long-term interest in the agreement's NAFTA interpretation, and, therefore, they may advance claims uninhibited by any discipline. This situation can be expected to lead to more aggressive interpretations of Chapter 11 by investors than the Parties would advance were they to commence a NAFTA state-to-state dispute settlement proceeding based upon an alleged breach of Chapter $11 .^{50}$

As discussed further below, even the Canadian implementation of the 1996 SLA and U.S. government conduct in the application of their AD/CVD laws have been targeted by softwood lumber companies under NAFTA c. 11.

\section{NAFTA CHAPTER 11, POPE \& TALBOT INC. V. CANADA, AND THE 1996-2001 CANADA-U.S. SOFTWOOD LUMBER AGREEMENT}

On 24 December 1998, Pope \& Talbot, Inc. (Pope \& Talbot), a U.S. corporation, submitted its Notice of Intent to submit an arbitration claim under NAFTA c. $11 .{ }^{51}$ Pope \& Talbot's affected investment was a British Columbia corporation that it fully controlled, Pope \& Talbot Ltd. (Pope \& Talbot Canada). Pope and Talbot Canada harvested timber and manufactured softwood lumber in British Columbia, exporting most of its lumber to the U.S., and Pope \& Talbot Canada was therefore subject to the 1996 SLA. ${ }^{52}$ It provided that there would not be any U.S. unfair trade actions against the Canadian softwood lumber industry for the life of the Agreement and required the Canadian government to manage the export of

$46 \quad$ Ibid., art. 1135. If restitution is ordered, NAFTA, ibid., art. 1135(1)(b) states that the award shall provide that the disputing party may pay monetary damages and interest in lieu of restitution.

Ibid., art. 1136.

See e.g. disputes listed online: NAFTA Claims <http://www.naftaclaims.com>.

Kinnear \& Hansen, supra note 35 at 110-13.

Thomas, supra note 35 at 102-103.

Pope \& Talbot, Inc. v. Canada, "Notice of Intent to Submit a Claim to Arbitration” (24 December 1998) and "Notice of Arbitration" (25 March 1999), online: NAFTA Claims <http://www.naftaclaims. com/disputes_canada_pope.htm> [Pope \& Talbot].

52 Supra note 24. 
covered softwood lumber into the U.S. ${ }^{53}$ The 1996 SLA export constraints only covered softwood lumber from four provinces, including British Columbia. ${ }^{54}$ Free export of lumber into the U.S. was allowed up to a certain level and then Canada was required to collect fees on issuance of export permits for lumber exported by companies in the covered provinces above this level. ${ }^{55}$ The regime was regulated through the allocation of annual quotas issued to eligible exporters. ${ }^{56}$

Pope \& Talbot argued that the Canadian government's implementation of the 1996 SLA violated its obligations under NAFTA arts. 1102 (national treatment), 1105 (minimum standard of treatment), 1106 (prohibition against performance requirements), and 1110 (expropriation) with respect to Pope \& Talbot Canada. The company claimed damages in the amount of US\$508 million. An arbitral tribunal was established in August 1999. ${ }^{57}$

In a decision on a preliminary motion to dismiss the investor's claim, the arbitral tribunal rejected the Canadian government's arguments that the claim fell outside c. 11 because it dealt with trade in goods rather than investment and that it addressed a treaty that could not be classified as a government measure. ${ }^{58}$ The tribunal found that various c. 11 substantive obligations were drafted in a manner that could encompass measures specifically directed at goods produced by a particular investment. ${ }^{59}$ The tribunal further decided that although the 1996 SLA was not a measure under c. 11, it was not directly in issue - rather, the conduct of Canada in implementing its SLA obligations was questioned, conduct capable of constituting measures within the scope of c. $11 .^{60}$

In its Interim Award on the Merits dated 26 June 2000, the tribunal decided that Canada had not violated its NAFTA art. 1106 (prohibition against performance requirements) and art. 1110 (expropriation) obligations. ${ }^{61}$

Pope \& Talbot argued that the SLA export control regime violated art. 1106 by: requiring Pope \& Talbot Canada to export softwood lumber in an amount lower than that which would be exported in the absence of an export fee system, penalizing the Canadian subsidiary for under-use of its quotas pursuant to "use it or lose it" rules, and conditioning the granting of reduced fees on the restriction of sales to the U.S. via the export control regime. ${ }^{62}$ The tribunal found that a violation of art. 1106 had not been made out because the export control regime did not "impose or enforce ... requirements" within the meaning of art. 1106(1)(a). ${ }^{63}$ Instead, it was considered to be a tariff-rate export restraint regime that, while it deterred increased exports to the U.S., did not constitute a requirement for the establishment,

1996 SLA, ibid., arts. I-III, annex 1.

Ibid., arts. II(1)-(2).

Ibid., art. II.

Ibid., art. II(1).

The three members were Canadian, American, and British.

Pope \& Talbot, “Award on Motion to Dismiss re: Whether Measure 'Relate to' the Investment” (26 January 2000), online: NAFTA Claims, supra note 51 at para. 38.

Ibid. at para. 26.

Ibid. at paras. 36-37.

Pope \& Talbot, “Interim Merits Award” (26 June 2000), online: NAFTA Claims, supra note 51.

Ibid. at paras. 47-48.

Ibid. at para. 75 . 
acquisition, expansion, management, conduct, or operation of a U.S. investment in Canada. ${ }^{64}$ Also, the tribunal found that since the export control regime did not impose any restrictions or limitations on domestic sales of softwood lumber there were no breaches of arts. $1106(1)(e)$ or $1106(3)(d){ }^{65}$

Article 1110 specifies that if a host state expropriates a covered NAFTA investment it must compensate the investor. ${ }^{66}$ In Pope \& Talbot, the tribunal accepted that the investment's access to the U.S. market was a property interest subject to protection under art. 1110 and that nondiscriminatory government regulation that may fall within the state's exercise of its police powers can fall within art. $1110 .{ }^{67}$ However, the tribunal found that Canada's regulatory measures, such as the export control regime, did not interfere with Pope \& Talbot Canada's business activities to the extent that direct or even creeping expropriation could be found. ${ }^{68}$ The evidence showed that Pope \& Talbot remained in full control of its subsidiary, it continued to export substantial quantities of softwood lumber to the U.S., and it continued to make substantial profits on those sales. ${ }^{69}$

The Award on the Merits was issued on 10 April 2001. ${ }^{70}$ The tribunal decided that there was no breach of art. 1102 (national treatment), but it did find that Canada had violated art. 1105 , the minimum standard of treatment principle, based on its conduct towards the investor in a verification review of Pope \& Talbot Canada's quota allocation conducted after the c. 11 claim had been lodged.

The national treatment provision in art. 1102 provides for treatment of the foreign investment/investor that is no less favorable than the host government accords in like circumstances to domestic investment/investors in areas such as acquisition, management, operation, and sale of the investment. ${ }^{71}$ Pope \& Talbot argued that the national treatment obligation of Canada had been violated because investors/investments both in covered

Ibid.

Ibid. at para. 80.

NAFTA, supra note 2, art. 1110.

Pope \& Talbot, "Interim Merits Award," supra note 61 at para. 96. See support for this “contemporary conception" of property in Methanex Corporation v. United States, "Final Award on Jurisdiction and Merits” (3 August 2005) 44 I.L.M. 1345 at 1457 [Methanex Corporation]. But also see Methanex Corporation at 1456: "[A]s a matter of general international law, a non-discriminatory regulation for a public purpose, which is enacted in accordance with due process and, which affects, inter alios, a foreign investor or investment is not deemed expropriatory and compensable unless specific commitments had been given by the regulating government to the then putative foreign investor contemplating investment that the government would refrain from such regulation." See Andrew Newcombe, "The Boundaries of Regulatory Expropriation in International Law" (2005) 20 ICSID Rev.F.I.L.J. 1 on permissible use of governmental regulatory or police powers in deprivation of property. Pope \& Talbot, ibid. at paras. 96, 100, 102, 105. The tribunal discussed the meaning of expropriation under art. 1110, ibid. at paras. 102-104. Subsequent c. 11 arbitral tribunals have elaborated on the meaning of art. 1110, see e.g. Feldman v. Mexico, "Award” (16 December 2002), 42 I.L.M. 625 at 64257 [Feldman]; Waste Management Inc. v. Mexico, “Award” (30 April 2004), 43 I.L.M. 967 at 994-1002 [Waste Management]; GAMI Investments, Inc. v. Mexico, "Final Award of the Tribunal on Jurisdiction and Merits” (15 November 2004), 44 I.L.M. 545 at 564-67 [GAMI Investments]; Methanex Corporation, ibid. at 1456-58.

Pope \& Talbot, "Interim Merits Award," ibid. at paras. 100-101.

Pope \& Talbot, "Final Merits Award" (10 April 2001), online: NAFTA Claims, supra note 51. NAFTA supra note 2, art. 1102. 
provinces and in provinces not subject to the 1996 SLA were given treatment that was more favorable than that extended to Pope \& Talbot Canada. The tribunal stated that applying the 1996 SLA only to the covered provinces was reasonably related to a rational policy of removing the threat of U.S. CVD actions, unmotivated by discrimination, since 95 percent of softwood lumber came from the these provinces and the U.S. had never made a final determination against softwood lumber from the excluded provinces. ${ }^{72}$ The tribunal found that softwood lumber producers in the excluded provinces were not in like circumstances with producers in the covered provinces with the result that Canada had not breached its art. 1102 obligations. ${ }^{73}$ Pope \& Talbot also argued that British Columbia's proportion of softwood lumber production and exports had declined during the SLA relative to the other covered provinces. Again, the tribunal found that this did not constitute a breach by Canada of its art. 1102 obligations - rather, the changes were due to economic factors, the investment was not in like circumstances to that of new entrants, and rules for new entrants were rational. ${ }^{74}$ Further, the mechanism whereby different fees were levied on coastal versus interior producers was not found to be based on any distinction between Canadian and foreign companies in B.C. and, hence, its implementation did not violate the national treatment obligation. ${ }^{75}$

The minimum standard of treatment obligation in NAFTA art. 1105(1) states: "Each Party shall accord to investments of investors of another Party treatment in accordance with international law, including fair and equitable treatment and full protection and security."76 In giving meaning to this obligation, the tribunal applied an "additive” interpretation, holding that the fairness elements in art. 1105(1) are additional to those obligations required in accordance with international law. ${ }^{77}$ This interpretation went against the language of art. 1105(1) which suggests that fair and equitable treatment is included within the larger international law minimum standard of treatment. Pope \& Talbot argued that a number of aspects of the export control regime violated art. 1105, but all of these with the exception of the verification review episode were found by the tribunal not to amount to breaches. ${ }^{78}$

The verification review was launched by the Canadian government after the company submitted its c. 11 notice of intent to look into the claim that Pope \& Talbot had not received the quota allocation to which it was entitled. ${ }^{79}$ During the review, the Canadian government required large amounts of business records to be brought to Canada and engaged in questionable conduct towards the investor. ${ }^{80}$ The evidence showed that Pope \& Talbot was treated exceptionally poorly compared with other companies subject to the regime. ${ }^{81}$ The

Pope \& Talbot, “Final Merits Award,” supra note 70 at para. 87.

Ibid. at para. 88.

Ibid. at paras. 93-95.

Ibid. at paras. 96-104. Subsequent c. 11 arbitral tribunals have engaged in further analysis of art. 1102, see e.g. Methanex Corporation, supra note 67 at 1442-50 which relied on Pope \& Talbot, "Final Merits Award," supra note 70 for its selection of the proper comparator in determining "like circumstances" (at 1445).

Supra note 2, art. 1105(1).

Pope \& Talbot, "Final Merits Award,” supra note 70 at paras. 110, 113, 115-18.

Ibid. at paras. 119-25.

Ibid. at para. 156.

Ibid. at paras. 156-70.

Ibid. at paras. 180-81. 
tribunal found that Canada's conduct during the review was a denial of fair and equitable treatment in violation of art. $1105 .^{82}$

The NAFTA state parties were unhappy with the inconsistent interpretations of NAFTA art. 1105(1) given by c. 11 tribunals. On 31 July 2001, pursuant to art. 1131(2) and before the Pope \& Talbot tribunal issued its award concerning damages, the NAFTA Free Trade Commission adopted a binding Interpretation of Article 1105(1). The Commission stated in part:

1. Article 1105(1) prescribes the customary international law minimum standard of treatment of aliens as the minimum standard of treatment to be afforded to investments of investors of another Party.

2. The concepts of "fair and equitable treatment" and "full protection and security" do not require treatment in addition to or beyond that which is required by the customary international law minimum standard of treatment of aliens. ${ }^{83}$

The Interpretation rejected the additive interpretation of art. 1105(1) used by the Pope \& Talbot tribunal. The tribunal issued its Award in Respect of Damages on 31 May 2002. ${ }^{84}$ The tribunal applied the Commission's Interpretation, considering it to be mandatory and not prospective in nature. ${ }^{85}$ Canada had relied on the 1926 Neer claim for the contents of the minimum standard of treatment, arguing that "egregious" conduct was required to breach the obligation. ${ }^{86}$ The tribunal canvassed the evolution of customary international law in this area which has arguably lowered the bar for a violation of the minimum standard of treatment obligation. ${ }^{87}$ However, it concluded that even if Canada's proposed, more stringent standard was applied, Canada would still be found in breach of its art. 1105(1) obligations with respect to the verification review. ${ }^{88}$ As a basis for their holding, the tribunal listed Canada's burdensome demand for documents, failure to provide information promised, threats to reduce and terminate Pope \& Talbot's export quotas, misrepresentations of facts by officials to the Minister of International Trade, and suggestions of criminal investigation of the

at paras. $171-81$

Foreign Affairs and International Trade Canada (FAITC), News Release, No. 116 "Pettigrew Welcomes NAFTA Commission’s Initiatives to Clarify Chapter 11 Provisions” (1 August 2001), online: FAITC $<$ http://w01.international.gc.ca/minpub/Publication.aspx?Redirect=True\&publication_id=378614 \&Language $=$ E\&docnumber $=116>$.

Pope \& Talbot, “Award on Damages” (31 May 2002), online: NAFTA Claims, supra note 51 [Damages Award].

85 Ibid. at paras. 51, 54. Subsequent c. 11 arbitral tribunals have analyzed post-Interpretation Art. 1105(1): see e.g. Waste Management, supra note 68 at 983-94; GAMI Investments, supra note 68 at 559-63; Methanex Corporation, supra note 67 at 647-51.

Pope \& Talbot, "Damages Award," ibid. at para. 57, citing United States (L.F. Neer) v. Mexico (1926), 4 R.I.A.A. 60 at $61-62$, stating that for treatment to violate international law it "should amount to an outrage, to bad faith, to wilful neglect of duty, or to an insufficiency of governmental action so far short of international standards that every reasonable and impartial man would readily recognize its insufficiency."

Pope \& Talbot, "Damages Award,” ibid. at paras. 54-65. See subsequent c. 11 awards e.g. Waste Management, supra note 68 at paras. 93, 98; International Thunderbird Gaming Corporation v. Mexico, "Final Award" (26 January 2006), online: NAFTA Claims <http://www.naftaclaims.com/ disputes_mexico_itgc.htm> at para. 194 [International Thunderbird]; Mondev International Ltd. $v$. United States, “Award” (11 October 2002), 42 I.L.M. 85 at para. 125. 
company. ${ }^{89}$ However, Canada was ordered to pay Pope \& Talbot only US\$461,566 in damages and interest. ${ }^{90}$

Two other U.S. softwood lumber companies, Ketcham Investments, Inc. and Tysa Investments, Inc., also brought a NAFTA c. 11 claim against Canada arguing that their Canadian investment was harmed by Canada's implementation of the 1996 SLA. ${ }^{91}$ However, the Ketcham/Tysa claim was abandoned before any arbitral proceedings started, likely influenced by the generally negative results in Pope \& Talbot.

\section{NAFTA CHAPTER 11, CANFOR CORPORATION AND TERMINAL FOREST PRODUCTS LTD. V. U.S.A.: THE REVIEWABILITY OF NAFTA AD/CVD ACTIONS AND THE BYRD AMENDMENT}

As discussed earlier, the 1996 SLA expired in 2001 and was followed immediately by new trade actions launched against Canadian softwood lumber producers by U.S. industry representatives, starting the Lumber IV episode. The NAFTA c. 11 consolidated softwood lumber case started life as separate complaints brought in 2001 to 2003 by four Canadian softwood lumber companies: Canfor Corporation (Canfor), Terminal Forest Products Ltd. (Terminal), Tembec et al. (Tembec), and Doman Industries Ltd. (Doman). ${ }^{92}$ Doman took no further action to pursue its claim. The remaining three companies each argued that the U.S. administration of the softwood lumber AD/CVD actions brought against the Canadian companies in Lumber IV was undertaken in an "discretionary, arbitrary, and cavalier" manner resulting in damage to their U.S. investments. ${ }^{93}$ The companies argued that they were attacking the conduct of U.S. government entities and officials in pursuing the AD/CVD actions and not the substance and enactment of the U.S. AD/CVD laws. ${ }^{94}$ They claimed that the U.S. government behaviour violated NAFTA arts. 1102, 1103, 1105, and 1110. Based on

$89 \quad$ Ibid. at para. 68.

$90 \quad$ Ibid. at paras. 90-92.

91 Ketcham Investments, Inc. and Tysa Investments Inc. v. Canada, "Notice of Intent to Submit a Claim to Arbitration” (20 December 2000), online: NAFTA Claims <http://www.naftaclaims.com/disputes canada_ketcham.htm>. Ketcham and Tysa were Washington State companies which indirectly controlled West Fraser Mills Ltd., a British Columbia company.

92 Canfor Corporation v. United States, "Notice of Intent to Submit a Claim to Arbitration” (5 November 2001), "Notice of Arbitration and Statement of Claim" (9 July 2002), online: NAFTA Claims <http://www.naftaclaims.com/disputes_us_canfor.htm> [Canfor]; Terminal Forest Products Ltd. v. United States, "Notice of Intent to Submit a Claim to Arbitration" (12 June 2003), "Notice of Arbitration” (31 March 2004), online: NAFTA Claims <http://www.naftaclaims.com/ disputes_us_terminal.htm> [Terminal]; Tembec, et al. v. United States, "Notice of Intent to Submit a Claim to Arbitration” (4 May 2002), “Notice of Arbitration and Statement of Claim” (3 December 2004), online: NAFTA Claims <http://www.naftaclaims.com/disputes_us_tembec.htm> [Tembec]; Doman Industries Ltd. v. United States, “Notice of Intent to Submit a Claim to Arbitration” (1 May 2002), online: NAFTA Claims <http://www.naftaclaims.com/disputes_us_doman. htm>. Canfor claimed US\$250 million in damages and costs, Tembec claimed US\$200 million, and Terminal claimed US\$90 million.

93 They disputed, for example, methods used by the DOC and ITC and argued that the DOC acted under political pressure to reach a particular result: Canfor and Terminal, “Decision on Jurisdiction” (6 June 2006), online: NAFTA Claims <http://www.naftaclaims.com/disputes_us_10.htm> at paras. 86-94, 116, 145 [Canfor/Terminal Decision on Jurisdiction]. Canfor, Tembec, and Doman were also participating in NAFTA c. 19 softwood cases. Canfor/Terminal Decision on Jurisdiction, ibid. at paras. 94, 146. 
arts. 1102, 1103, and 1105, Canfor and Terminal also claimed damages for losses to their U.S. investment caused by the Byrd Amendment, a U.S. statutory provision enacted in 2000 which stipulated that CVDs and ADDs collected by the U.S. government be distributed annually to the affected U.S. producers. ${ }^{95}$ In 2003, the WTO Appellate Body held that the Byrd Amendment was inconsistent with U.S. WTO obligations in the GATT 1994, AD Agreement, and SCM Agreement. ${ }^{96}$ On 8 February 2006, the U.S. government repealed the Byrd Amendment, allowing the U.S. industry to continue to receive duties collected until 1 October 2007. ${ }^{97}$

The companies gave information in their claims that they had investments in the U.S. to which much of their Canadian softwood lumber was sold for resale to U.S. customers, with remanufacturing of the lumber sometimes also taking place at their U.S. companies. ${ }^{98}$ On 7 September 2005, the three claims were consolidated pursuant to NAFTA art. 1126(2) with a new tribunal assuming jurisdiction over the claims. ${ }^{99}$

Not surprisingly, the U.S. argued that the subject matter in the claims could only be dealt with under NAFTA c. 19 and could not be argued under c. 11. On 6 June 2006, the tribunal issued its lengthy decision on the preliminary question of jurisdiction. ${ }^{100}$ The decision also confirmed that Tembec had withdrawn from the consolidated proceedings. ${ }^{101}$

The main argument revolved around the interpretation of NAFTA art. 1901(3) which states: "Except for Article 2203 (Entry into Force), no provision of any other Chapter of this Agreement shall be construed as imposing obligations on a Party with respect to the Party's antidumping law or countervailing duty law." ${ }^{102}$ The U.S. government argued that art. 1901(3) should be construed to mean that the U.S. had not consented to arbitrate the claims of the companies under c. 11 and that no jurisdiction under c. 11 exists for AD/CVD matters. ${ }^{103}$ In construing the meaning of various terms in art. 1901(3), the tribunal used arts. 31 and 32 of the Vienna Convention on the Law of Treaties ${ }^{104}$ which it considered were reflective of customary international law and, thus, applicable pursuant to art. 1131(1). ${ }^{105}$

Ibid. at para. 289; Continued Dumping and Subsidy Offset Act of 2000, Pub. L. 106-387, Title X, §1002, 114 Stat. 1549 at 1549A-72 (2000) (codified as amended at 19 U.S.C. §1675c (2000)), repealed by Pub. L. 109-171, Title VII, Subtitle F, §7601(a), 120 Stat. 154 (2006) [Byrd Amendment]. United States - Continued Dumping and Subsidy Offset Act of 2000, supra note 28.

By the end of 2005, approximately US\$5 million had been distributed to producers: Canfor/Terminal Decision on Jurisdiction, supra note 93 at paras. 283, 288.

Canfor, "Notice of Intent to Submit a Claim to Arbitration," supra note 92 at paras. 4-7; Terminal, "Notice of Arbitration,' supra note 92 at paras. 9-13; Tembec, "Notice of Arbitration," supra note 92 at paras. $12-13$.

Canfor, Tembec, and Terminal "Consolidation Tribunal - Order 01" (17 December 2005), online: NAFTA Claims <http://www.naftaclaims.com/disputes_us_10.htm>. The tribunal members were Canadian, American, and Dutch. By Procedural Order No. 1, the tribunal decided to determine its jurisdiction pursuant to art. 1901(3) in a preliminary phase and leave all other U.S. objections to jurisdiction and admissibility to the merits phase of the proceedings.

Canfor/Terminal Decision on Jurisdiction, supra note 93.

Ibid. at paras. 20-29. See infra note 134.

Supra note 2, art. 1901(3).

Canfor/Terminal Decision on Jurisdiction, supra note 93 at paras. 95-114.

23 May 1969, 1155 U.N.T.S. 331, 8 I.L.M. 679 (entered into force 27 January 1980) [Vienna Convention].

Canfor/Terminal Decision on Jurisdiction, supra note 93 at paras. 177-78, 192. 
The tribunal held that the interpretation of the phrase "the Party's antidumping law or countervailing duty law" in art. 1901(3) covers "a very broad spectrum of matters," its interpretation is governed by the definitions in art. 1902(1), and the enlarged phrase "with respect to the Party's antidumping law or countervailing duty law” includes the application of that law. ${ }^{106}$

The tribunal explicitly addressed the issue of concurrent fora inside the NAFTA with respect to AD/CVD actions under both cc. 19 and 11 . The companies took the position that cc. 19 and 11 provide concurrent fora so that both could be used. They argued that cc. 19 and 11 are complementary because they are so "dramatically different" in terms of substantive law (domestic versus international respectively) and remedial processes. ${ }^{107}$ They further argued that c. 19 does not expressly refer to c. 11 and vice versa. ${ }^{108}$ While NAFTA art. 2004 excludes c. 19 matters from the inter-state dispute settlement mechanism, the tribunal recognized that "Chapter Eleven does not have a corresponding express exclusion pertaining to Chapter Nineteen matters. Articles 1108 and 1138 set forth a number of exceptions and exclusions, but Chapter 19 is conspicuously absent from that list." 109

The tribunal took the position that the NAFTA drafters "sought to avoid concurrent or parallel proceedings." 110 They did recognize that, with investment claims, the NAFTA does allow for the same measure to be considered by two different fora inside NAFTA because such claims can be sent to c. 20 inter-state dispute settlement in addition to use of c. 11 by investors. ${ }^{111}$ However, the tribunal concluded: "Nonetheless, when it comes to NAFTA's mechanisms for dispute settlement, it cannot be presumed that the drafters intended to create an open-ended, multiple fora system"112 and "[i]n the Tribunal's opinion, the presumption of the NAFTA is that, in the absence of an express provision to the contrary, concurrent or parallel proceedings are to be avoided."

The tribunal found that NAFTA art. 1901(3) barred c. 11 arbitration of the investors' claims. Since the application of art. 1901(3) led to the finding that there was no U.S. consent to arbitrate such a claim, the tribunal found that it did not have jurisdiction to decide on the claims to the extent they concerned U.S. AD/CVD law, including the conduct of the DOC, the ITC, and other government entities/officials prior to, during, and after preliminary and final determinations in relation to U.S. AD/CVD laws. ${ }^{114}$

Ibid. at paras. 204-11, 220. NAFTA, supra note 2, art. 1902(1) states in part: "Antidumping law and countervailing duty law include, as appropriate for each Party, relevant statutes, legislative history, regulations, administrative practice and judicial precedents." Canfor/Terminal Decision on Jurisdiction, ibid. at para. 125.

$108 \quad$ Ibid. at para. 122.

Ibid. at para. 223. The tribunal noted that some restrictions and exceptions with respect to c. 11 are found in other NAFTA chapters: ibid. at para. 224. 
However, the tribunal found that the U.S. Byrd Amendment did not form part of U.S. AD/CVD laws under art. 1901(3) because, assuming that the Amendment pertained to U.S. CVD and AD law, the U.S. had failed to bring it within the covered definition of AD/CVD law because the U.S. had not followed the requirements of art. 1902(2) ${ }^{115}$ Pursuant to art. 1902(2), amendments to a NAFTA state's CVD/ADD laws will only apply to goods from another NAFTA state provided that listed criteria are satisfied, including that: the amendment must specify that it applies to the other NAFTA state's goods (art. 1902(2)(a)); the amending state must notify in writing the other affected NAFTA state of the amending statute as far in advance as possible of the date of enactment of the statute (art. 1902(2)(b)); and the amendment is not inconsistent with the GATT, its Antidumping or Subsidies Codes, or any successor agreements (such as the WTO Agreement), or with the object and purpose of the NAFTA and c. 19 (art. 1902(2)(d)(i) and (ii)). ${ }^{116}$

The U.S. admitted that it had not notified Canada of the Byrd Amendment, and the tribunal found that this lack of "timely notification" meant that the U.S. had not satisfied the requirements of art. 1902(2)(b). ${ }^{117}$ The tribunal took into account U.S. conduct contemporaneous with or proximate to enactment of the Byrd Amendment - which indicated that the U.S. government did not consider the Amendment to be part of its AD/CVD laws to support its conclusion that the Byrd Amendment did not fall within U.S. AD/CVD law in art. 1901(3). ${ }^{118}$ The tribunal also indicated that, based on findings in a 2006 CIT decision, the U.S. had not complied with art. 1902(2)(a) requiring that the Amendment specify it applied to Canadian goods. ${ }^{119}$ In addition, based on the WTO proceedings which found the Byrd Amendment to be in breach of U.S. WTO obligations, the tribunal found it questionable whether the U.S. had complied with art. 1902(2)(d)(i). ${ }^{120}$ Further, in obiter, the tribunal stated that the Byrd Amendment "would appear conceptually not to come within what has commonly been understood as antidumping and countervailing duty law in many countries and internationally." 121

As a result, the tribunal held that it had jurisdiction over the Byrd Amendment claim. ${ }^{122}$ However, in October 2006 a new Canada-U.S. Softwood Lumber Agreement terminated the Canfor c. 11 claim and separate negotiations terminated Terminal’s claim. ${ }^{123}$

Thus, unfinished issues with respect to the Byrd Amendment claim remain. Were Canfor and Terminal "investors" with "investment" in the U.S. within the meaning of NAFTA c. 11 ?

115 Ibid. at paras. 294, 334, 347-48, pursuant to NAFTA, arts. 1902(1) and 1903(1).

116 Ibid. at paras. 321, 324. NAFTA, supra note 2, art. 1902(2)(c) requires consultation following notification and prior to the amendments's enactment on request of NAFTA state(s) to which the amendment applies.

117 Canfor/Terminal Decision on Jurisdiction, ibid. at paras. 303, 315. Widespread press reports about the Byrd Amendment and actual Canadian awareness of the Amendment were insufficient to satisfy NAFTA, art. 1902(2)(b): Canfor/Terminal Decision on Jurisdiction, ibid. at paras. 310, 312. Ibid. at paras. 324, 334. The U.S. position in the WTO panel proceedings addressing the Byrd Amendment was that the Amendment was a government payment program that had nothing to do with administration of its AD/CVD laws: ibid. at paras. 325-28. Ibid. at paras. 331-32. See Canadian Lumber, supra note 29 at 1333-34, Pogue J.

Ibid. at para. 333.

Ibid. at para. 330.

Ibid. at para. 336.

See infra note 134 and accompanying text. 
The facts in the applicants' initial claims indicated that they had investments in the U.S. that would easily fall within the definition in NAFTA art. 1139. Did the U.S. actions fall within the definition of "measures" as defined in NAFTA art. 201? The definition is non-exhaustive and includes a "practice," so that a pattern of behaviour or conduct by government officials can constitute a measure, similar to the conduct of the Canadian government officials in the Pope \& Talbot arbitration, discussed earlier, which was found to fall within the definition. Did the Byrd Amendment violate U.S. substantive obligations in arts. 1102, 1003, and 1105? The Canfor/Terminal tribunal actually stated that the companies had prima facie demonstrated that the Byrd Amendment may have conferred financial benefits on U.S. investors/investments competing with those of the claimants "demonstrably contrary" to NAFTA art. 1102 (national treatment), an indication that Canfor and Terminal had a reasonably good case on the merits. ${ }^{124}$ If there was a violation of NAFTA c. 11 did such breach result in loss or damage to the Canadian companies? Furthermore, if damage occurred, what damage if any did the Canadian lumber companies suffer with respect to their U.S. investments? Would it be only the smaller losses incurred by their U.S. marketing/remanufacturing companies or would it also include the lost profits incurred by the softwood lumber manufacturers in Canada ${ }^{125}$

\section{The 2006 CANADA-U.S. SofTWOod LUMBER AgreEMENT}

On 27 April 2006, the Canadian and U.S. governments reached an agreement in principle to end the latest softwood lumber dispute through another managed trade agreement. ${ }^{126}$ The 2006 Softwood Lumber Agreement between the Government of Canada and the Government of the United States of America was signed on 12 September 2006 and, as amended, entered into force on 12 October 2006. ${ }^{127}$ The 2006 SLA covers listed softwood lumber products and applies to most but not all provinces/territories. ${ }^{128}$ The U.S. government agreed to revoke retroactively all duties, terminate all unfair trade actions against Canadian softwood lumber for the duration of the agreement, and return the approximately $\$ 5$ billion in duties collected since 2002. ${ }^{129}$ In return, the Canadian government agreed to pay US\$1 billion to listed entities (including the CFLI) and impose export charges and a permit system on Canadian softwood lumber sold into the U.S. ${ }^{130}$ The 2006 SLA has a term of seven years, which can be

Ibid. at para. 341.

See S.D. Myers, Inc. v. Canada, "Damages Award" (21 October 2002), online: NAFTA Claims $<$ http://www.naftaclaims.com/disputes_canada_sdmyers.htm>. See also high fructose corn syrup (HFCS) cases: Corn Products International, Inc. v. Mexico (2005), ICSID Case No. ARB (AF)/04/01 (NAFTA Ch. 11); Archer Daniels Midland Company and Tate \& Lyle Ingredients Americas, Inc. v. Mexico (2005), ICSID Case No. ARB (AF)/04/5 (NAFTA Ch. 11), online: ICSID <http://www.world bank.org/icsid/cases/pdf/15_Order_Consolidation_Tribunal_Corn_ADM_e.pdf $>$.

FAITC, News Release, No. 45, "Canada's Trade and Industry Ministers and Ambassador to the U.S. Welcome the Long-Awaited Agreement to End the Canada-U.S. Softwood Lumber Dispute" (27 April 2006), online: FAITC <http://w01.international.gc.ca/minpub/Publication.aspx?isRedirect=True\& publication_id $=383934 \&$ Language $=E \&$ docnumber $=45>$.

12 September 2006, online: FAITC <http://www.international.gc.ca/eicb/softwood/SLA-main-en.asp> (as am., entered into force 12 October 2006) [2006 SLA].

2006 SLA, ibid., arts. I, X, annexes 1A, 10 (softwood lumber from the Maritime provinces, Yukon, North West Territories, and Nunavut is excluded, as is lumber produced by listed, mainly Quebec companies). Ibid., arts. III-V, annexes 3A, 5A, 5B.

Ibid., arts. VI-VII, annexes 2C(4)-(5), 13. The charges apply when the price of lumber is equal to or lower than US\$355 per million board feet and the provinces/regions can choose one of two types of export measures. 
extended by an additional two years. ${ }^{131}$ Also, there is a twelve-month standstill on the initiation of U.S. trade remedy actions that will take effect on the expiry of the 2006 SLA. ${ }^{132}$ However, the 2006 SLA can be terminated by either party on six months notice after it has been in force for 18 months, although the 12-month standstill period will also apply on such termination. ${ }^{133}$

Most importantly, with respect to the ongoing softwood lumber disputes, the 2006 SLA provides for the settlement of all claims listed therein, including the NAFTA c. 11 Canfor claim, with the Terminal claim withdrawn separately in early $2007 .{ }^{134}$ Furthermore, art. XI(2) of the 2006 SLA states:

The operation and application of Section B of Chapter Eleven of the NAFTA is hereby suspended with respect to any matter arising under the SLA 2006 and any measure taken by a Party that is necessary to give effect to or implement the SLA 2006. Consequently, no claim under Section B of Chapter Eleven of the NAFTA may be made against a Party by investors of the United States or Canada in respect of any such matter or measure. $^{135}$

Article XI(2) addresses the Pope \& Talbot case by eliminating the availability of the c. 11 host state-investor arbitral mechanism for all claims concerning the 2006 SLA and its implementation. ${ }^{136}$ Although stated in reciprocal, comprehensive terms, this provision is clearly a response to U.S. investors in Canada who might be inclined to contest the Canadian export control regime under the 2006 SLA and it prevents another c. 11 arbitral claim that mimics Pope \& Talbot. The 2006 SLA, however, does not contain any provisions which prevent Canadian softwood lumber producers (other than Canfor with respect to its earlier claim) from launching new c. 11 claims contesting U.S. government measures affecting their U.S. investments that are unconnected with the 2006 SLA.

Ibid., art. XVIII.

The U.S. lumber industry has agreed that they shall not file petitions and shall oppose initiation of domestic trade actions and the U.S. government has agreed not to self-initiate such actions during this 12 month period, ibid., art. XVIII, annex 18.

Ibid., art. XX(1).

2006 SLA, ibid., arts. II(1)(a)-(b), annexes 2A (Settlement of Claims Agreement signed inter alia by Canfor), 2B. Annex 2A(1) states that the Settlement of Claims Agreement constitutes a full and complete settlement of the Canfor claim in the NAFTA c. 11 Canfor/Terminal v. United States claim. Annex 2A(10) prohibits parties to the Claims Settlement Agreement from re-filing any of the listed actions. On the separate termination of Terminal's c. 11 claim see Canfor Corp. v. United States, Tembec et al. v. United States, Terminal Forest Products Ltd. v. United States, Joint Order on the Costs of Arbitration and for the Termination of Certain Arbitral Proceedings (19 July 2007), online: Investment Treaty Arbitration <http://ita.law.uvic.ca/documents/Canfor-Tembec-Terminaljointorder.pdf $>$ at para. 81. This Joint Order also noted that Tembec's c. 11 claim was "not extant or pending as a legal matter" in September 2006 (at paras. 129, 150).

Ibid., art. XI(2).

Ibid., art. XI(2). 


\section{NAFTA CHAPTER 11, SOFTWOOD LUMBER, AND IMPLICATIONS FOR THE FUTURE}

The NAFTA c. 11 Pope \& Talbot case illustrates that Canada's implementation of softwood lumber export controls under a bilateral managed trade agreement can fall within the scope of NAFTA c. 11. However, the Pope \& Talbot award found that the basic structure and implementation of the export control regime was not in breach of any of the substantive provisions of NAFTA c. 11. The conduct found to violate NAFTA art. 1105 was unusual, probably exceptional, and not part of the usual legislative and administrative measures taken in the implementation of a managed trade agreement. Thus, the normal administration of an export control regime for softwood lumber or any other product is unlikely to run afoul of c. 11. However, in a cautious move, Canada and the U.S. closed off this avenue of relief for U.S. investors in Canada covered by Canadian export controls in the 2006 SLA and will very likely try to do so in any and all future bilateral softwood lumber agreements. Along with the Free Trade Commission's Interpretation of art. 1105, art. XI(2) of the 2006 SLA is another example of NAFTA government action to circumscribe the application of NAFTA c. 11 by subsequent agreement. However, while the Interpretation is an agreement between all three NAFTA states authorized by NAFTA, ${ }^{137}$ the latter is an attempt by the two relevant governments to rein in the perhaps unexpected wide-ranging investor claims concerning trade-related measures. Questions are already being raised about the legality under international law of art. XI(2) of the 2006 SLA. Can two of the three NAFTA states modify the operation of c. 11, s. B of the NAFTA by bilateral agreement or, from another perspective, can two of the NAFTA states suspend the operation of a portion of the NAFTA between themselves, when there is no authorization for such action in the NAFTA itself? ${ }^{138}$ While the applicability and intricacies of the relevant international law principles are beyond the scope of this article, there is a resulting uncertainty about the effect of art. XI(2) of the 2006 SLA on the operation of c. 11 of the NAFTA, and affected NAFTA investors may contest art. XI(2) through the c. 11 arbitral process. ${ }^{139}$

The tribunal in Methanex Corporation, supra note 67 at 1453, discussed the international law on treaties with respect to the Free Trade Commission Interpretation, noting that art. 39 of the Vienna Convention, supra note 104, states that a treaty can be amended by agreement between the parties and no particular form of agreement is required. Also, art. 31(3) of the Convention states that in interpreting a treaty any subsequent agreement between the parties regarding the application of the treaty or the application of its provisions shall be taken into account. Article 31 is widely considered to be reflective of customary international law: see e.g. Methanex Corporation, ibid. at 1446; Canfor/Terminal Decision on Jurisdiction, supra note 93 at para. 177.

See Matthew T. Simpson, “Chopping Away at Chapter 11: The Softwood Lumber Agreement's Effect on the NAFTA Investor-State Dispute Resolution Mechanism,” Comment, (2007) 22 Am U. Int'l L. Rev. 479, arguing that art. XI(2) affects NAFTA c. 11 in a manner inconsistent with customary international law on treaties. NAFTA c. 11 and its annexes do not exclude softwood lumber issues from the purview of c. 11, and art. 1138 does not exclude softwood lumber/SLA matters from c. 11 dispute settlement. NAFTA art. 2202(1) permits modifications of the NAFTA with the agreement of "the Parties" which should, according to international norms on treaty interpretation, be construed to mean the agreement of all three NAFTA state parties.

Simpson, ibid., argues that art. XI(2) of the 2006 SLA violates the provisions of arts. 41(1) (modification of a treaty between some of the parties only) and 44 (suspension of part of treaty/separability of treaty provisions when listed criteria satisfied) of the Vienna Convention, supra note 104. Since the U.S. is not a contracting party to the Vienna Convention, these provisions are only applicable if they reflect customary international law which is binding on all states. Simpson argues that both arts. 41(1) and 44 reflect customary international law, but draws this conclusion essentially based on his position that the entirety of the Vienna Convention is reflective of custom: ibid. at 496-98. While a number of its 
The 2006 c. 11 arbitral tribunal decision on jurisdiction in the Canfor/Terminal case tries to strikes a balance between limiting intra-NAFTA dispute settlement fora to contest domestic AD/CVD actions and keeping NAFTA c. 11 available for related measures affecting investment. The Canfor/Terminal decision closes off the use of NAFTA c. 11 by Canadian softwood lumber companies to contest U.S. AD/CVD actions when the impugned U.S. laws and conduct can be considered to be part of U.S. AD/CVD laws and their application. But it does not completely close the door to the use of c. 11 by Canadian softwood lumber companies. Canadian companies could use c. 11 to contest future amendments of U.S. CVD/AD law applied to their lumber exports as falling outside the scope of art. 1901(3) based on the various grounds used in Canfor/Terminal. In order to use c. 11, such amendments would have to fail to meet the criteria laid down in NAFTA art. 1902(2), including statutory language applying the law to Canadian goods, formal notification to the Canadian government of the amendment, and consistency of the amendment with the GATT 1994, the WTO AD and SCM Agreements and the object and purpose of the NAFTA and its c. $19 .{ }^{140}$ Further, the Canfor/Terminal tribunal, albeit in obiter dicta, indicated that an amendment which does not fall with the concept of AD/CVD laws as commonly understood on an objective basis may not be considered by a c. 11 tribunal to be part of the body of c. $19 \mathrm{AD} / \mathrm{CVD}$ laws protected from scrutiny under c. $11 .{ }^{141}$ However, given its experience with the Byrd Amendment in the Canfor/Terminal case, when the U.S. amends its AD/CVD laws with general application in the future, it is unlikely that the U.S. will fail to specify in the statute that the changes apply to its NAFTA partners and fail to notify and consult with its partners about the amendments. Thus, only amendments which run afoul of the listed WTO agreements or the object and purpose of the NAFTA and its c. 19, and/or reforms which could be construed as falling outside the concept of AD/CVD laws, are likely to be contested under c. 11 in future years.

In addition, as noted above, there is nothing in the 2006 SLA to prevent a Canadian softwood lumber company (other than Canfor, with Terminal ending its claim separately) from bringing a c. 11 claim at any time while the 2006 SLA is still in force, arguing that their U.S. investments have suffered loss or damage due to the past operation of the U.S. Byrd Amendment or due to any other U.S. measure that is unconnected to the 2006 SLA and not otherwise excluded by application of the reasoning in the Canfor/Terminal decision. ${ }^{142}$

provisions have been found to codify customary norms, this general conclusion can be disputed and a more in-depth examination of the contours of the customary norms on treaty modification and treaty suspension/severability and whether they are exactly reflected in arts. 41(1) and 44 is warranted. See e.g. Ian Brownlie, Principles of Public International Law, 6th ed. (Oxford: Oxford University Press, 2003) at 580; Seyed Ali Sadat-Akhavi, Methods of Resolving Conflicts between Treaties (Leiden, Neth.: Martinus Nijhoff Publishers, 2003); D.W. Greig, Invalidity and the Law of Treaties (London: British Institute of International and Comparative Law, 2006). However, Canada and the U.S. will likely argue that they have satisfied the customary international law requirements underpinning art. XI(2). Mexico may not contest art. XI(2) if it takes the position that its rights and obligations under NAFTA have not been affected.

See supra notes 115-22 and accompanying text. GATT 1994 and the WTO AD and SCM Agreements are annexed to the WTO Agreement, the successor agreement to those listed in NAFTA art. 1902(2)(d)(i) that binds the NAFTA states: supra note 1.

141 See supra note 121 and accompanying text.

142 NAFTA, supra note 2, art. 1116(2) states that an investor cannot make a claim if more than three years have elapsed from the date on which it first acquired, or should have first acquired knowledge of the alleged breach and its incurring of loss or damage. The Byrd Amendment, supra note 95, was enacted in 2000 and allows redistribution of AD/CVD duties to the U.S. industry until 1 October 2007. It can 
Indeed, on 16 April 2007, Domtar Inc., a Canadian softwood lumber producer with two U.S. subsidiaries, filed a c. 11 claim against the U.S. for losses it states it incurred because of the U.S. AD/CVD determinations covering Canadian softwood lumber, the Byrd Amendment, and the 2006 SLA. ${ }^{143}$ Domtar is arguing that the U.S. has violated articles 1102 (national treatment), 1103 (most-favored-nation treatment), 1104 (better of treatment required by arts. 1102 and 1103), 1105 (minimum standard of treatment), and 1109 (no restrictions on transfers relating to the investment).

The reasoning in the Canfor/Terminal decision on jurisdiction will be very persuasive in the deliberations of the Domtar arbitral tribunal. Domtar is arguing that political pressures placed by the U.S. lumber industry and elements in the U.S. executive and legislative branches on the U.S. AD/CVD investigating agencies influenced these agencies to decide in favor of the U.S. industry. ${ }^{144}$ Allegations are also made that ex parte communications from the U.S. Congress, executive agencies, and the lumber industry to the investigating agencies were not disclosed as required by law. ${ }^{145}$ The Canfor/Terminal investors also criticized the conduct of the investigating agencies and argued that they acted under political pressure. ${ }^{146}$ As a result, it is likely that the Domtar tribunal will follow the Canfor/Terminal case and hold that it likewise does not have jurisdiction to examine the merits of that part of the claim concerning the U.S. AD/CVD determinations. It is not out of the question, however, that the issue of the ex parte communications could make a difference in the Domtar case if the tribunal makes an exception to the Canfor/Terminal holding for egregious and illegal behavior.

The strongest element of the Domtar claim is the Byrd Amendment argument. The Canfor/Terminal decision found that the Amendment fell outside U.S. AD/CVD law under art. 1901(3) and so the tribunal had jurisdiction to hear the argument on the merits. ${ }^{147}$ Again, it is likely that the Domtar tribunal will follow this aspect of the Canfor/Terminal decision. Domtar argues that the Byrd Amendment and its implementation violate NAFTA arts. 1102 and $1104 .^{148}$

With respect to the 2006 SLA, Domtar's argument appears to be that NAFTA art. 1109 was breached by the 2006 SLA because it required that Canada pay a portion of the returnable duty deposits made by Canadian softwood lumber companies to listed entities (including US\$500 million to the CFLI, representing a large segment of the U.S. lumber industry), with the result that Domtar did not receive about twenty percent of the cash deposits to which it

be argued that damage was incurred by Canadian softwood lumber companies with U.S. investments every time the U.S. government redistributed AD/CVDs to U.S. producers, but any redistributions should have ended at the latest on the implementation of the 2006 SLA. On this basis, if Byrd Amendment softwood lumber duty redistributions occurred into 2006, the affected Canadian producers would have up until the corresponding month in 2009 to launch a c. 11 claim.

Domtar Inc. v. United States, "Notice of Arbitration and Statement of Arbitration Claim” (16 April 2007), online: U.S. Department of State < www.state.gov/s/l/c22195.htm> [Domtar]. Domtar is claiming US\$200 million in damages. 
was entitled. ${ }^{149}$ Unlike the Pope \& Talbot case, the 2006 SLA is directly implicated in Domtar's claim so, supported by the Pope \& Talbot holding that the 1996 SLA was not a "measure" under c. 11, it is quite possible that the Domtar tribunal will find that it cannot address this aspect of the claim. ${ }^{150}$ Further, since Domtar has included the 2006 SLA in its claim, art. XI(2) of the 2006 SLA becomes relevant to potentially bar a c. 11 tribunal from considering the 2006 SLA and its implementation. Accordingly, it is likely that the Domtar tribunal will have to address the effect of art. XI(2) on this portion of the claim at the jurisdictional stage and, thus, delve into the legality of this bilateral initiative under international law. ${ }^{151}$

Even if a c. 11 tribunal finds that it has jurisdiction over an AD/CVD-related claim (for example, in Domtar), the claim will still have to be examined on its merits. As discussed earlier, the Canfor/Terminal claim would have had several good arguments on the merits concerning the effects of the Byrd Amendment had the case advanced further. However, similar c. 11 claims launched by other companies will have to be examined on their own distinct facts. In addition, an early termination of the 2006 SLA on the grounds of alleged breach of the treaty by one of the two states could lead to examination of the legal status of the settlement of the Canfor c. 11 claim. $^{152}$

The Canfor/Terminal tribunal found a relatively good balance that limits the use of c. 11 to contest AD/CVD laws of the other NAFTA states yet retains a small window of opportunity for its use. This window is based on a textual interpretation of c. 19. The decision strictly circumscribes the use of concurrent fora inside the NAFTA, thereby avoiding the possibility of inconsistent results and promoting certainty and efficiency of NAFTA dispute resolution. However, the result of the Canfor/Terminal decision is that even egregious NAFTA government administration of its AD/CVD laws (for example, denial of hearings, abusive behaviour by officials) which ultimately causes damage or loss to NAFTAcovered investments cannot be contested for its negative impact on investment either under NAFTA c. 11 or under c. 19 if the AD/CVD laws fall within the c. 19 definitions. ${ }^{153}$ In this respect, the question can be raised whether the Canfor/Terminal tribunal should have left an opening for the use of c. 11 in the more extreme situations of government maladministration of its $\mathrm{AD} / \mathrm{CVD}$ laws in the investment context. It must be kept in mind that there is no legal principle of stare decisis governing c. 11 arbitral awards. Thus, c. 11 arbitral tribunals are

Ibid. at paras. 118-127; supra note 130 and accompanying text; 2006 SLA, supra note 127, annex 2C(5). Pope \& Talbot, “Award on Motion,” supra note 58 and accompanying text. Also, a relevant "measure" in the context of the Domtar case would be U.S. government conduct in the implementation of the 2006 SLA. Canadian government conduct is not relevant when it is a Canadian investor alleging that the U.S. government has violated its c. 11, s. A obligations. In the Domtar case, the direct source of the damage is annex $2 \mathrm{C}(5)$ of the 2006 SLA (Canadian government payment of US\$1 billion to listed entities) and its implementation by the Canadian government.

Supra notes 138, 139 and accompanying text; Simpson, supra note 138 at 511-12.

2006 SLA, supra note 127, annex 2A(1). Unhappy with Canadian implementation of the 2006 SLA, the U.S. requested formal consultations under the 2006 SLA in late March 2007: Steven Chase, "U.S. raises new objections to Canada’s softwood trade” The Globe and Mail (31 March 2007) A16; Julian Beltrame, "Ottawa talks seek to save fragile lumber truce” The Globe and Mail (19 April 2007) B4. In August 2007, the U.S. commenced an international arbitration against Canada pursuant to art. XIV of the 2006 $S L A$, arguing Canada has breached the SLA, online: Foreign Affairs and International Trade Canada $<$ http://www.international.gc.ca/eicb/softwood/SLA-main-en.asp\#settlement>.

NAFTA c. 19 binational panels do not have the jurisdiction to examine investment claims. See supra notes 16-21 and accompanying text for discussion of the parameters of c. 19 binational panel review. 
free to depart from the legal reasoning in the Canfor/Terminal decision in deciding similar claims in the future. However, in practice c. 11 tribunals often do rely on the legal principles in relevant earlier awards for guidance in their own reasoning, with the result that the Canfor/Terminal decision will be influential in the resolution of any future c. 11 claims involving $\mathrm{AD} / \mathrm{CVD}$ laws. In this respect, if the Domtar claim goes to c. 11 arbitration, the tribunal will have to decide whether to follow the Canfor/Terminal decision without qualification or make an exception for egregious agency conduct. The Domtar tribunal may also have to determine the important issue of the legality under international law of art. XI(2) of the 2006 SLA.

\section{ConClusion}

A combination of c. 11 arbitral jurisprudence and government agreement, specifically the c. 11 Free Trade Commission Interpretation and art. XI(2) of the Canada-U.S. 2006 SLA, has led to the situation that NAFTA c. 11 will have relatively limited utility for softwood lumber companies unless future arbitral tribunals take a different approach in interpreting the NAFTA and also refuse to give effect to art. $\mathrm{XI}(2)$ based on treaty law principles. In particular, NAFTA government action and c. 11 jurisprudence has had considerable effect in circumscribing the availability of c. 11 as one of the multiple fora that can be used to contest U.S. AD/CVD action against Canadian softwood lumber exports in post-2006 SLA disputes, although c. 11 remains open to Canadian investors in some cases while the 2006 SLA is still in force. Indeed, in the NAFTA Canfor/Terminal claim the arbitral tribunal squarely addressed multiple fora and adopted a philosophy of avoidance of concurrent fora inside the NAFTA, giving supremacy to c. 19 for the resolution of AD/CVD disputes. NAFTA c. 11, however, can still be used to attack U.S. government measures concerning Canadian softwood lumber, but only if the measures can be categorized as falling outside the definition of U.S. AD/CVD laws in c. 19 based on discrete, technical exceptions. While this development goes a long way in reducing the availability of intra-NAFTA concurrent fora for claims against domestic AD/CVD actions, the concurrent fora in the WTO, NAFTA c. 19, and domestic courts remain available to complicate future softwood lumber disputes.

The NAFTA c. 11 softwood lumber cases also illustrate the continuing moves by NAFTA governments to try to limit the scope of their c. 11 obligations and the overall careful application of c. 11 by NAFTA arbitral tribunals. ${ }^{154}$ While the softwood lumber companies may have launched their c. 11 complaints in a desperate move to find another avenue for redress, their claims have merit. However, the reactions by the NAFTA governments, in particular the U.S. and Canada, and the c. 11 arbitral jurisprudence indicate that NAFTA c. 11 claims in general will face an increasingly uphill battle for success. 